\title{
Quality Optimization of Hot Filled Pasteurized Fruit Purees: Container Characteristics and Filling Temperatures
}

\author{
Filipa V. M. Silva \& Cristina L. M. Silva* \\ Escola Superior de Biotecnologia-UCP, Rua Dr. António Bernardino de Almeida, \\ P-4200 Porto, Portugal
}

\begin{abstract}
A mathematical model was developed to describe the pasteurization, by hot filling, of fruit purees. The model assumed that the puree reaches instantaneously a hot-fill temperature and, after introduced into the container, cooling by conduction takes place. The heat transfer was modelled by a finite differences method. Vitamin $C$ and pectinesterase were used as quality and pasteurization criteria, respectively.

Specific filling temperatures combined with container dimensions are required to achieve a target pasteurization value. However, only some of the adequate conditions offer final products with maximum quality.

Several simulations were carried out to investigate the effect of filling temperature, container shape, type of cooling medium and pasteurization value on final quality retention expressed as vitamin $C$ retention. Using statistical factorial analysis the most important parameters affecting quality were filling temperature and pasteurization value, followed by cooling medium. Shape was not considered significant ( $\mathrm{p}>0.05$ ). Best quality was achieved with higher hot filling temperatures and small pasteurization values.
\end{abstract}

\section{NOTATION}

$C \quad$ Level of the quality attribute at time $t$

$\left(C / C_{c}\right) \quad$ Quality retention

$D \quad$ Decimal reduction time $(\mathrm{min})$

Gr Grashof number (dimensionless)

${ }^{*}$ Author to whom correspondence should be addressed. Tel: 351-2-5580058; fax: 351-2-590351; e-mail: crislui@esb.ucp.pt 


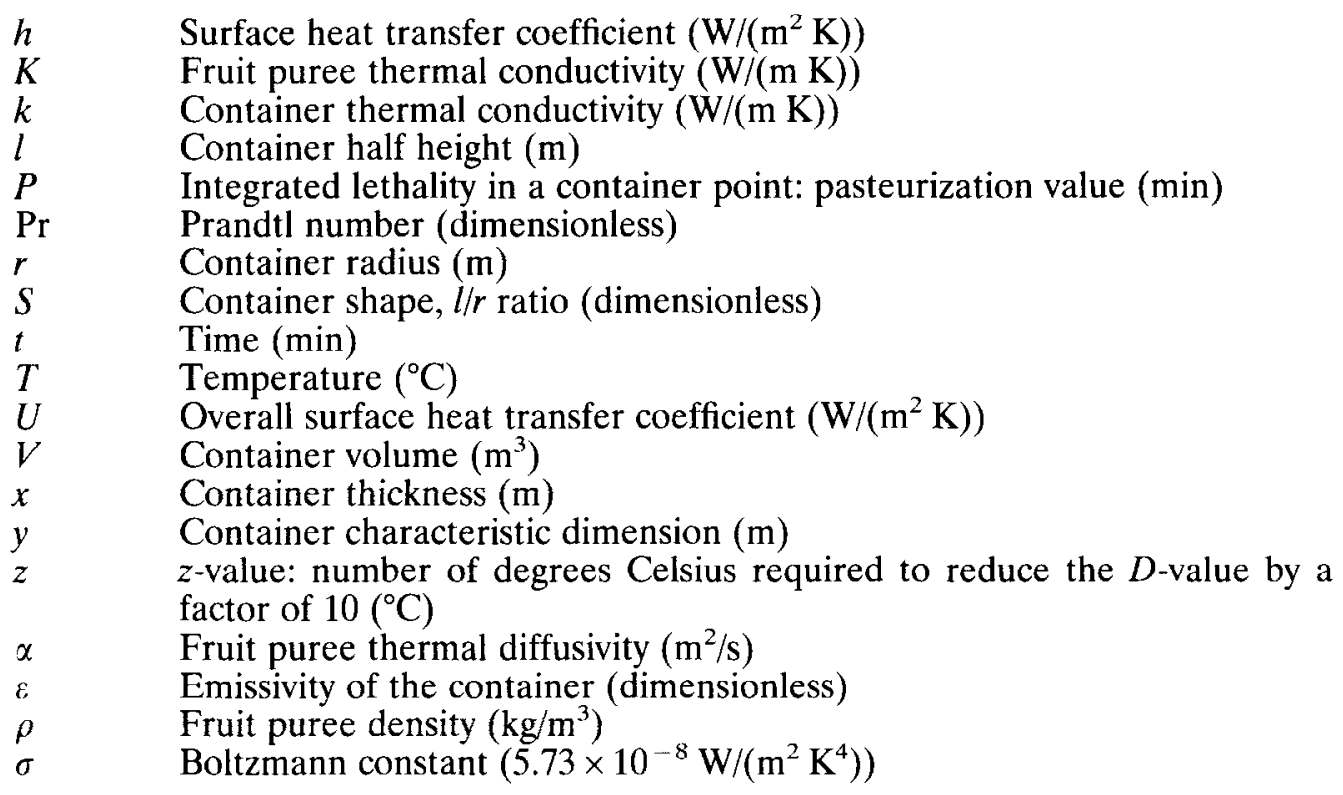

\section{Subscripts}

$\begin{array}{ll}0 & \text { Initial time or time zero } \\ \text { air } & \text { Air } \\ \text { ave } & \text { Volume average } \\ \text { c } & \text { Natural convection } \\ \text { e } & \text { Enzyme } \\ \text { F } & \text { Refers to hot filling temperature } \\ \mathrm{q} & \text { Quality } \\ \mathrm{r} & \text { Radiative } \\ \text { refe } & \text { Enzyme reference temperature } \\ \text { refq } & \text { Quality parameter reference temperature } \\ \mathrm{s} & \text { Container surface } \\ \mathrm{T} & \text { Total } \\ \text { water } & \text { Water } \\ \infty & \text { Cooling medium }\end{array}$

\section{INTRODUCTION}

Fruit purees, besides being consumed directly as desserts or as a complement of cooked meats, such as apple puree, are used as ingredients in various food products: e.g. juices, nectars, jams, ice creams, baby foods, pastry. Several chemical-free processes can be used for its preservation: cooling, freezing, pasteurization, sterilization or combined processes such as pasteurization followed by low temperature storage. Pasteurization is a mild heat treatment where only the vegetative microbial cells 
(bacteria, yeasts and moulds) and enzymes are inactivated. The treatment must target the microbial and enzyme inactivation, while maintaining the original organoleptic and nutritive fruit characteristics (Fellows, 1988). The severity of the heat treatment and the resulting shelf-life are determined mostly by the fruit $\mathrm{pH}$ (Fellows, 1988). Most parts of the fruits have low $\mathrm{pH}(<4.6)$ and therefore existing spores will not grow and will not be a main concern. In these cases, a pasteurization process should be enough for fruit preservation at ambient temperature. Sometimes natural fruit enzymes are more heat resistant than vegetative cells. In these cases the pasteurization process criterion is based upon enzyme inactivation. For instance, the thermal resistance of gram-positive non-spore-forming bacteria and yeast was found to be very low as compared with peroxidase and pectinesterase (Aung \& Ross, 1965; Peralta ct al., 1973).

The hot fill technique is a simple pasteurization process and can be easily implemented for acid fruit purees. The fruit puree is considered to reach a given hot filling temperature instantaneously and, after filling into the container, cooling by conduction takes place (Sandoval et al., 1994). Given a filling temperature, specific container dimensions are required in order to achieve a target volume average pasteurization value for the most thermal resistant microorganism or spoilage enzyme (Sandoval et al., 1994). Some research work concerning the use of pasteurization by hot filling for fruit purees or pastes has been reported in the literature. Nanjundaswamy et al. (1973) determined thermal process conditions for canned mango products. The authors concluded that filling temperature was very important in minimizing process time and ensuring adequate mango isolated yeast and peroxidase thermal inactivation. For $0.571401 \times 411$ cans, filling temperatures between 76 and $80^{\circ} \mathrm{C}$ were required to achieve product stabilization. After filling, during the cooling phase, the cans were sealed and kept inverted for 2-3 minutes for lid 'sterilization'. This procedure was enough to ensure adequate commercial 'sterility'. Although there was no microbial inoculation before the thermal process, the process was industrially validated by analysing final enzyme and microbiological levels. Nath \& Ranganna (1983a) determined process requirements and heat transfer characteristics for hot filled guava pulp. For hot fill cool procedures of fruits with a pH value lower than 4.0, the National Canners Association recommends the following process: a filling temperature higher than $85^{\circ} \mathrm{C}$, followed by can sealing and $2 \mathrm{~min}$ immersion in steam or water at $88^{\circ} \mathrm{C}$ before cooling. However, the above procedure failed in small Indian canneries, because there was a holding time of $10-30 \mathrm{~min}$ between sealing and processing. In this work the authors studied and validated the existing thermal process. Can sizes of $401 \times 411$ were used for heat penetration tests. The effect of two different holding times $(10$ and $30 \mathrm{~min})$, filling temperatures $\left(72-88^{\circ} \mathrm{C}\right)$ and corresponding process time on the final pasteurization value $(P$ value) was evaluated. Inoculated pack studies were also carried out to test for commercial sterility. Using Fourier's law analytical solutions to model the heat transfer process, Sandoval et al. (1994) predicted the time-temperature relationships during air cooling following the hot fill process for tomato paste in glass jars. Three jar sizes and five filling temperatures were investigated. Hot filling temperatures of at least 94,92 and $90^{\circ} \mathrm{C}$ for jar sizes of $0.2,0.5$ and 41 , respectively, were suggested. These filling temperature-container size combinations ensure product microbial safety. The target microorganism employed was Bacillus coagulans and the pasteurization value at $90^{\circ} \mathrm{C}\left(P_{90^{\circ}} \mathrm{C}\right)$, for an initial microbial population of $10^{5}$ per jar, was $24.5 \mathrm{~min}$. 
No optimization of the hot filling thermal processes, in terms of maximizing final quality retention, was investigated in the previous mentioned works. All the authors focused their attention on the process requirements in order to achieve a required $P$-value for adequate commercial pasteurization. Several pasteurization conditions (filling temperature, container radius and half-height, heating medium conditions, etc.) can achieve the same pasteurization value required for a specific fruit puree preservation. However, only one set of thermal treatment conditions gives maximum quality retention of the fruit pulp. The idea of minimizing quality losses during thermal processing of foods is not new and several quality optimization studies are available in the literature in the field of sterilization of prepackaged foods (Holdsworth, 1985; Silva et al., 1994). The optimization is possible because the thermal degradation kinetics of quality factors such as colour, flavour, texture or nutrients is much less temperature sensitive than the destruction of microorganisms or enzymes (Teixeira et al., 1969; Lund, 1977; Holdsworth, 1985). Nevertheless, few foodapplied quality optimization studics wcre previously reported, except for a sterilization study with white beans in brine (Van Loey et al., 1993) and another with canned tuna (Banga et al., 1993). Furthermore, no quality optimization study with fruit puree/juice was found in the literature. The same happens with optimization of a hot filling process in general.

The objectives of this work were as follows:

(1) The development of a mathematical model to describe the pasteurization of a food product during the cooling phase of a hot fill process; experimental validation of predicted time-temperature profiles during the cooling phase.

(2) To study the effect of filling temperature, cooling medium (overall heat transfer coefficient), $P$-value and container shape on the container size required and corresponding achieved final quality retention.

\section{MODELLING AND SIMULATION}

In this section the mathematical model developed and used in all the simulations is described. Only the cooling phase of the hot fill pasteurization was modelled. The pasteurization achieved during cooling was assumed to be much larger than the pasteurization obtained during the puree heating and filling processes. The error committed with this assumption will never be dangerous in terms of product pasteurization and consumer safety. The product would probably be slightly overprocessed and never the contrary. Holding time was considered zero in all the simulations, and therefore, a specific pasteurization value was achieved based on adequate hot filling temperature-container size combination, instead of temperature-holding time. Heat transfer by conduction was predicted by a finite differences mathematical method. The constituents used for pasteurization criterion and quality evaluation were pectinesterase and vitamin $\mathrm{C}$, respectively. All the simulations were carried out using the thermal characteristics of cupuaçu fruit (Theobroma grandiflorum), an Amazon high valuable crop (Table 4). This fruit has an average $\mathrm{pH}$ of $3.4,10.5-10.8{ }^{\circ} \mathrm{Brix}$ and vitamin $\mathrm{C}$ content ranges from 14.43 to $28.32 \mathrm{mg} / 100 \mathrm{~g}$ (Barbosa et al., 1978; Chaar, 1980; Oliveira, 1981; IBGE, 1981; Miranda, 1989).

A factorial design analysis was done to evaluate the main effects of different processing variables on quality retention and required container volume. The processing variables studied were: filling temperature $\left(T_{\mathrm{F}}\right)$; type of cooling medium 
(water vs. air), i.e., overall heat transfer coefficient $(U)$; volume average pasteurization value $\left(P_{\text {ave }}\right)$ and container shape $(S)$.

\section{Heat transfer model}

A PASCAL computer program was developed to model the pasteurization by an hot fill process. A finite cylindrical geometry was assumed as well as constant thermophysical properties (food thermal conductivity, thermal diffusivity and density). Heat transfer by conduction during the cooling by air or water was described by a finite differences method using non-capacitance surface nodes (Chau \& Snyder, 1988; Chau \& Gaffney, 1990; Silva, 1993). The overall surface heat transfer coefficient, $U$, which was determined using empirical equations (Holman, 1990), includes the resistances of the container wall, $x / k$, external radiation, $h_{\mathrm{r}}$, and external natural convection, $h_{\mathrm{c}}$ (eqns 1,2 , and $3,4,5$ in Table 1 ):

$$
U=\frac{1}{\frac{1}{h_{\mathrm{c}}+h_{\mathrm{r}}}+\frac{x}{k}}
$$

where $x$ and $k$ are the container thickness and thermal conductivity, respectively, and

$$
h_{\mathrm{r}}=\varepsilon \times \sigma \times \frac{\mathrm{T}_{\mathrm{s}}^{4}-\mathrm{T}_{r}^{4}}{\mathrm{~T}_{\mathrm{s}}-\mathrm{T}_{r}}
$$

where $\varepsilon$ is the container emissivity, $\sigma$ the Boltzmann constant $\left(5.73 \times 10^{-8} \mathrm{~W} /\right.$ $\left(\mathrm{m}^{2} \mathrm{~K}^{4}\right)$ ), and $T_{\mathrm{s}}$ and $T_{\infty}$ the container surface and cooling medium temperatures, respectively. The radiation and container wall resistances are much smaller than the external natural convection resistance. The external natural convection coefficient

TABLE 1

Empirical Equations for Prediction of Natural Convection Surface Heat Transfer Coefficients in Vertical Cylindrical Walls (Holman, 1990)

\begin{tabular}{llll}
\hline $\begin{array}{l}\text { Cooling } \\
\text { medium }\end{array}$ & Flow & $G r \times \operatorname{Pr}$ & $h_{c}\left(W /\left(m^{2} . K\right)\right)$ \\
\hline Air & Laminar & $10^{4}-10^{9}$ & $1.42 \times\left(\frac{\mathrm{T}_{\mathrm{s}}-\mathrm{T}_{\mathrm{s}}}{\mathrm{y}}\right)^{\frac{1}{4}}$ \\
Water & Laminar & $10^{4}-10^{9}$ & $203 \times\left(\frac{\mathrm{T}_{\mathrm{s}}-\mathrm{T}_{2}}{\mathrm{y}}\right)^{\frac{1}{4}}$ \\
Water & Turbulent & $>10^{9}$ & $315 \times(\mathrm{y})^{\frac{1}{4}} \times\left(\mathrm{T}_{\mathrm{s}}-\mathrm{T}_{\mathrm{x}}\right)^{\frac{2}{2}}$
\end{tabular}




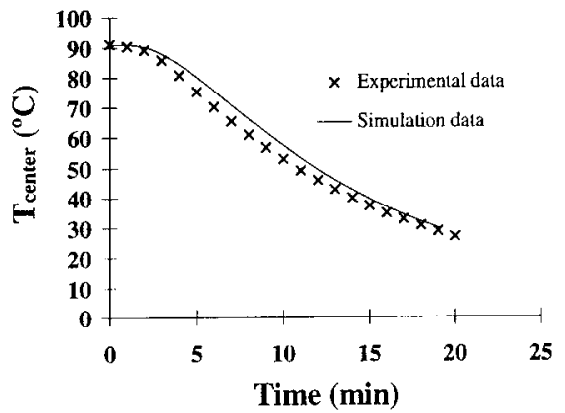

Fig. 1. Temperature at the container geometric centre as a function of time during the water cooling of cupuaçu in tin plate cans $\left(T_{0}=91^{\circ} \mathrm{C}, T_{\text {water }}=11^{\circ} \mathrm{C}, r=3.6 \mathrm{~cm}, l=1.75 \mathrm{~cm}\right)$.

varies with the type of cooling medium, type of flow, cylinder characteristic dimension (height or diameter), $y$, and temperature difference between the container surface and environmental temperature (eqns 3,4 and 5 in Table 1). During the cooling process, temperature gradient, $T_{s}-T_{\infty}$, decreases because the container surface temperature decreases; therefore, $h_{\mathrm{c}}$ also decreases and so does the overall surface heat transfer coefficient, $U$.

The conduction heat transfer equations and their solution using a finite differences method have been described in other previously published works (Chau \& Snyder, 1988; Chau \& Gaffney, 1990; Silva, 1993).

Cupuaçu (Theobroma grandiflorum), a tropical fruit from the Amazon, was used for the experimental validation of the predicted time-temperature history. Two experiments involving water and air cooling were carried out (Figs 1 and 2). Each experimental data curve was obtained using a thermocouple inserted at the container geometric centre coupled to a data acquisition system.

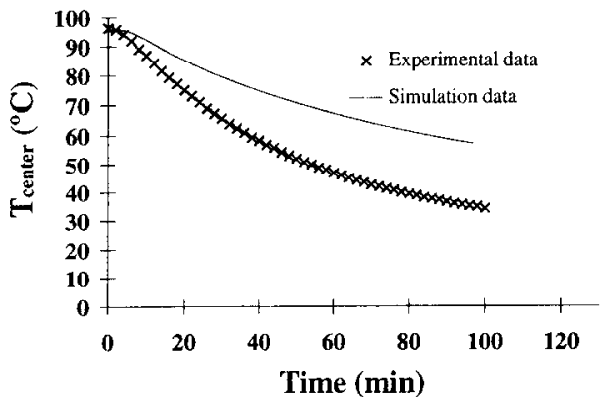

Fig. 2. Temperature at the container geometric centre as a function of time during the air cooling of cupuaçu in tin plate cans $\left(T_{0}=96^{\circ} \mathrm{C}, T_{\text {air }}=21^{\circ} \mathrm{C}, r=3.6 \mathrm{~cm}, l=1.75 \mathrm{~cm}\right)$. 
TABLE 2

Fruit Characteristics and Pectinesterase (PE) Inactivation Kinetic Data

\begin{tabular}{|c|c|c|c|c|c|c|c|}
\hline Fruit & Medium & $p H$ & $\begin{array}{l}\text { Soluble } \\
\text { solids } \\
\left({ }^{\circ} \text { Brix) }\right.\end{array}$ & $\begin{array}{l}D_{85^{\circ} \mathrm{C}} \\
(\mathrm{min})\end{array}$ & $\begin{array}{c}z_{e} \\
\left({ }^{\circ} \mathrm{C}\right)\end{array}$ & $\begin{array}{l}\text { Trange } \\
\left({ }^{\circ} \mathrm{C}\right)\end{array}$ & Reference \\
\hline Papaya & Puree & $\begin{array}{l}3.5 \\
3.8 \\
4.0\end{array}$ & $7-9$ & $\begin{array}{l}4.8 \\
5.7 \\
7.2\end{array}$ & $\begin{array}{l}14.8 \\
14.7 \\
14.2\end{array}$ & $75-85$ & Argáiz (1994) \\
\hline Papaya & $\begin{array}{l}\text { Acidified } \\
\text { pulp }\end{array}$ & 4.0 & $10-12$ & 3.9 & 15.0 & $82-102$ & Nath \& Ranganna (1981) \\
\hline Papaya & Nectar & 3.8 & 14 & 5.0 & 15.1 & $75-85$ & Argáiz (1994) \\
\hline Mandarin orange & Juice & $\begin{array}{l}3.6 \\
4.0\end{array}$ & $\begin{array}{l}12 \\
12\end{array}$ & $\begin{array}{l}2.2 \\
3.6\end{array}$ & $\begin{array}{l}11.4 \\
10.1\end{array}$ & $82-94$ & Nath \& Ranganna (1977) \\
\hline
\end{tabular}

\section{Pasteurization target and quality parameter: kinetics used for the simulations}

Most parts of the fruits are acid $(\mathrm{pH}<4.6)$, and thercfore microbial spores do not grow. Due to this fact, thermal processes are designed based on the inactivation of the most thermal resistant enzyme. Examples of these enzymes are peroxidase and pectinesterase (Dastur et al., 1968; Nanjundaswamy et al., 1973; Nath \& Ranganna, $1977,1980,1981,1983 \mathrm{a}, 1983 \mathrm{~b}$ ). If not inactivated, these enzymes have deterioration effects on the fruit quality. Pectinesterase (PE) is an enzyme often present in several tropical fruits - guava, papaya, mango, grapefruit, orange, mandarin (Table 2) and can be used as pasteurization criterion. Several studies have already been done to determine PE thermal degradation kinetics in different fruits. All the authors used first-order inactivation kinetic models (Table 2).

In all the simulations carried out in this study, the PE kinetic data of Argáiz (1994) in papaya puree at $\mathrm{pH} 3.5$ was used once the $\mathrm{pH}$ and soluble solids of this fruit are similar to those of cupuaçu fruit puree. All the simulations were done using cupuaçu thermal properties (Table 4).

During cooling, the pasteurization value ( $P$-value) at a single point of the container was computed using eqn (6):

$$
P=\int_{0}^{t_{\mathrm{T}}} 10^{\frac{T-T_{\text {ricki. }}}{\gamma_{i}}} \partial t
$$

To use this equation, enzyme inactivation kinetic parameters are necessary: $T_{\text {refe }}$, reference temperature for the enzyme; and $z_{\mathrm{e}}$-value for the enzyme. Temperatures lower than $55^{\circ} \mathrm{C}$ were considered to have negligible lethality and were not included for pasteurization value calculations.

The quality indicator used for process optimization was vitamin $C$. This very heatlabile vitamin is an important nutritional component present in several fruits. Table 
TABLE 3

Fruit Characteristics and Vitamin C Inactivation Kinetic Data

\begin{tabular}{|c|c|c|c|c|c|c|c|}
\hline Fruit & Medium & $p H$ & $\begin{array}{l}\text { Soluble } \\
\text { solids } \\
\left({ }^{\circ} \text { Brix) }\right.\end{array}$ & $\begin{array}{l}D_{85^{\circ} \mathrm{C}} \\
(\text { min) }\end{array}$ & $\begin{array}{l}z_{q} \\
\left({ }^{\circ} \mathrm{C}\right)\end{array}$ & $\begin{array}{c}\text { T range } \\
\left({ }^{\circ} \mathrm{C}\right)\end{array}$ & Reference \\
\hline Grapefruit & Juice & 3.1 & 11.8 & 296 & 124 & $61-96$ & Saguy et al. (1978) \\
\hline $\begin{array}{r}\text { Mandarin } \\
\text { (Sierra) }\end{array}$ & Juice & - & 11.1 & 406 & 47 & $20-92$ & Alvarado \& Viteri (1989) \\
\hline $\begin{array}{r}\text { Mandarin } \\
\text { (Costa) }\end{array}$ & Juice & - & 13.4 & 542 & 58 & $20-92$ & Alvarado \& Viteri (1989) \\
\hline Grapefruit & Juice & - & 11.2 & 829 & 44 & $20-92$ & Alvarado \& Viteri (1989) \\
\hline $\begin{array}{l}\text { Lemon } \\
\text { (Sicrra) }\end{array}$ & Juice & - & 7.6 & 1147 & 72 & $20-92$ & Alvarado \& Viteri (1989) \\
\hline Lime & Juice & - & 6.3 & 741 & 44 & $20-92$ & Alvarado \& Viteri (1989) \\
\hline
\end{tabular}

3 shows inactivation kinetic studies of vitamin $\mathrm{C}$ in several fruits. First-order kinetics modelled adequately the inactivation kinetics of vitamin $\mathrm{C}$ in all the reported work.

During the pasteurization process, quality retention $\left(C / C_{0}\right)$ at a single point in the container can be calculated using eqn (7):

$$
\frac{C}{C_{0}}=10\left(\frac{-1}{D_{\text {refq }}} \int_{0}^{t_{T}} 10^{\frac{T-T_{\mathrm{rtit}}}{\tau_{4}}} \partial t\right)
$$

where Trefq is the reference temperature for vitamin $C$ thermal inactivation, and $z q$ and $D$ refq are the $z$-value and decimal reduction time at the reference temperature for the quality parameter (vitamin $\mathrm{C}$ ), respectively. In this work the kinetic quality parameters chosen refer to vitamin $\mathrm{C}$ kinetics in mandarin juice with $11.1^{\circ} \mathrm{Brix}$.

\section{Simulation data}

Table 4 presents the cupuaçu fruit properties and kinetic data used in all computer simulations. The cupuaçu thermal diffusivity was determined experimentally using the Dickerson (1965) method. The pasteurization value, $(P)$, and vitamin $C$ retention, $\left(C / C_{0}\right)$, can be determined at the container centre, surface or in terms of volume average. Usually the container's coldest point is the point used for $P$-value calculation. In this work the cooling phase is being modelled and therefore underprocessing would occur when the container surface is chosen, whereas overprocessing would occur if the centre is chosen. This is the reason why a target volume average pasteurization value was chosen (eqn 8) (Sandoval et al., 1994). Once vitamin $\mathrm{C}$ is established as a nutritional quality indicator, the overall quality retention (Silva et al., 1992) can also be calculated (eqn 9): 
TABLE 4

Input Data for Simulations

\begin{tabular}{|c|c|c|}
\hline \multicolumn{2}{|c|}{ Cupuaçu properties/kinetic data } & $\begin{array}{l}\text { Source } \\
\text { Empirical equations (Sweat, 1986) }\end{array}$ \\
\hline $\begin{array}{l}K \\
\rho \\
x\end{array}$ & $\begin{array}{l}0.539 \mathrm{~W} /\left(\mathrm{m} .{ }^{\circ} \mathrm{C}\right) \\
1031( \pm 0.003) \mathrm{kg} / \mathrm{m}^{3} \\
1.671( \pm 0.124) \times 10^{-7} \mathrm{~m}^{2} / \mathrm{s}\end{array}$ & $\begin{array}{l}\text { Empirical equations (Sweat, 1986) } \\
\text { Experimentally determined, picnometer } \\
\text { Experimentally determined (Dickerson, 1965) }\end{array}$ \\
\hline $\begin{array}{l}T_{\text {rete }} \\
D_{\text {retic }} \\
z_{\text {w }}\end{array}$ & $\begin{array}{l}85^{\circ} \mathrm{C} \\
4.8 \min \\
14.8^{\circ} \mathrm{C}\end{array}$ & $\begin{array}{l}\text { Pectinesterase inactivation in papaya puree, } \mathrm{pH}=3.5 \\
\text { (Argáiz, 1994) }\end{array}$ \\
\hline $\begin{array}{l}T_{\text {reli }} \\
D_{\text {refic }} \\
z_{4}\end{array}$ & $\begin{array}{l}85^{\circ} \mathrm{C} \\
406 \text { min } \\
47^{\circ} \mathrm{C}\end{array}$ & $\begin{array}{l}\text { Vitamin C deterioration in mandarin juice, } 11.10^{\circ} \text { Brix } \\
\text { (Alvarado \& Viteri, 1989) }\end{array}$ \\
\hline
\end{tabular}

$$
\begin{gathered}
P_{\text {ave }}=\frac{1}{V_{\mathrm{T}}} \int_{0}^{V_{\mathrm{T}}} P \partial V \\
\left(\frac{C}{C_{0}}\right)_{\mathrm{ave}}=\frac{1}{V_{\mathrm{T}}} \int_{0}^{V_{\mathrm{r}}} \frac{C}{C_{0}} \partial V
\end{gathered}
$$

where $V$ is the container volume.

Heat transfer characteristics of tin plate cans with cupuaçu puree were used in all the computer simulations. Overall surface heat transfer coefficients were recalculated during the simulated cooling process (eqns 1 and 2, and 3, 4, 5 in Table 1) and ranged between 3 and $50 \mathrm{~W} /\left(\mathrm{m}^{2} \mathrm{~K}\right)$ for air cooling and 92 and $1000 \mathrm{~W} /\left(\mathrm{m}^{2} \mathrm{~K}\right)$ for water cooling, both at $20^{\circ} \mathrm{C}$.

\section{Factorial simulation design}

In order to study effectively linear and quadratic effects of four different processing variables on the final volume average quality retention of the product as well as the container volume required, a modified factorial design and analysis were performed (Box \& Behnken, 1960; Box et al., 1978). Statistical software, Statgraphics (Version 5 ), was used for analysis. Three-level factor design was carried out for filling temperature $\left(T_{\mathrm{F}}=70,90,110^{\circ} \mathrm{C}\right), P$-value $\left(P_{\text {ave }}=5,10,15 \mathrm{~min}\right)$ and container shape $(S=l / r=0.2,1.0,2.0)$. The water cooling versus air cooling variable, which corresponds to different $U$ values, was studied at two levels. Values of 26 and $546 \mathrm{~W} /\left(\mathrm{m}^{2} \mathrm{~K}\right)$ ) were the average of $U$ for air and water free convection cooling, respectively. The values for filling temperature and container shape were chosen from within the practical range. In commercial canning of fruit products a $P$-value between two decimal reductions, 2D, and 3D is recommended (Nath \& Ranganna, $1977,1980,1981,1983 \mathrm{~b})$. Consequently, $P$-values of 10 and $15 \mathrm{~min}$, which correspond approximately to $2 \mathrm{D}$ and $3 \mathrm{D}$ respectively, for $\mathrm{PE}$ inactivation were tested in 
the computer simulations. A total of 54 computer simulations were conducted: 27 for water cooling and the other 27 for air cooling. For every simulation, a certain container volume is required, for a specific filling temperature, in order to achieve a given volume average $P$-value. Each set of pasteurization conditions results in a specific product quality. Container volume and product quality retention responses are directly related and cannot be studied separately.

\section{RESULTS AND DISCUSSION}

\section{Experimental validation of the predicted time-temperature history}

Two experiments involving water and air cooling were carried out for the experimental validation of the predicted time-temperature history in the can centre. Cupuaçu pulp was canncd using tin platc cans with $3.6 \mathrm{~cm}$ radius and $1.75 \mathrm{~cm}$ halfheight. The experiment of cooling with water at $11^{\circ} \mathrm{C}$ is shown in Fig. 1. The hot-filling temperature was $91^{\circ} \mathrm{C}$ and the container geometric centre reached $30^{\circ} \mathrm{C}$ after approximately $20 \mathrm{~min}$. For cooling with air at $21^{\circ} \mathrm{C}$ (Fig. 2) approximately 120 min were necessary to reach $30^{\circ} \mathrm{C}$ at the container centre. The computer program temperature predictions were successfully validated for water cooling. On the other hand, average differences, between experimental and predicted temperatures, of approximately $15^{\circ} \mathrm{C}$ were observed for air cooling. Hence, it was concluded that the empirical equations used for surface heat transfer coefficient prediction, during air cooling, were not very accurate.

\section{Simulation results}

A total of 54 simulations were conducted to evaluate the effect of four different processing variables on product (cupuaçu) final quality. Vitamin $\mathrm{C}$ retention was the quality factor predicted by the computer simulations. Specific pasteurization conditions $\left(T_{\mathrm{F}}, P_{\text {ave }}, U, S\right)$ were tested in each computer simulation case study and a certain container volume $(V)$ is required to achieve the target volume average $P$ value. For each case, volume average quality retention was computed. When using the same set of conditions $\left(T_{\mathrm{F}}, P_{\text {ave }}, S\right)$, the $\left(C / C_{0}\right)_{\text {ave }}$ is slightly lower for air cooling than water cooling. Table 5 shows the range of container volumes and quality

TABLE 5

Range of Volume and Quality Retention Values Obtained with the Simulations

\begin{tabular}{lccccc}
\hline \begin{tabular}{c} 
Cooling medium \\
\multicolumn{1}{c}{ at $20^{\circ} \mathrm{C}$}
\end{tabular} & \multicolumn{2}{c}{ Air } & \multicolumn{3}{c}{ Water } \\
\hline Simulation conditions & $T_{\mathrm{F}}\left({ }^{\circ} \mathrm{C}\right)$ & 110 & 70 & 110 & 70 \\
$\quad$ (input) & $P_{\text {ave }}(\mathrm{min})$ & 5 & 15 & 5 & 15 \\
& $S$ & 0.2 & 0.2 & 1.0 & 0.2 \\
Predicted/calculated & $V(\mathrm{l})$ & $6.9 \times 10^{-5}$ & 68.4 & $3.85 \times 10^{-3}$ & 755 \\
Results (output) & $\left(C / C_{0}\right)_{\text {ave }}$ & 0.992 & 0.198 & 0.995 & 0.268 \\
\hline
\end{tabular}


retention obtained in all different simulations. Volumes can go up to 7551 if water cooling is used. Handschuh (1995) reports that transportation of juices, purees or concentrates from South America to Europe can be done in soft/rigid tanks with volumes up to 10001 . Larger filling temperatures $\left(110^{\circ} \mathrm{C}\right)$ and smaller $P$-values $(5 \mathrm{~min})$ require very small container sizes $(\leq 15.3 \mathrm{ml})$ and give the product best final quality $(>0.99)$. For air cooling, filling temperatures of $110^{\circ} \mathrm{C}$ require container volumes smaller than $0.535 \mathrm{ml}$. Those volumes are not commercially feasible. Therefore for cupuaçu fruit and using the kinetics mentioned before, filling temperatures closer to $110^{\circ} \mathrm{C}$ should not be used, to avoid overprocessing.

In Fig. 3, the Pareto chart shows the standardized effects of different parameters on product volume average quality retention, $\left(C / C_{0}\right)_{\text {ave }}$. An effect that exceeds the vertical line (critical $t$-value, $x=0.05$ ) may be considered significant. The most important factors in decreasing order are $T_{\mathrm{F}}$ and $P_{\text {ave }}$, followed by $U$. Quality retention is not a linear function of $T_{\mathrm{F}}$ and $P_{\text {ave }}$ because $\left(T_{\mathrm{F}}\right)^{2}$ and $\left(P_{\text {ave }}\right)^{2}$ also have a significant effect on $\left(C / C_{0}\right)_{\text {ave }}$. The interaction effect of $T_{\mathrm{F}}$ and $P_{\text {ave }}$, given by $T_{\mathrm{F}} \times P_{\text {ave }}$, arises from a difference in $\left(C / C_{0}\right)_{\text {ave }}$ sensitivity to $P_{\text {ave }}$ changes for different filling temperatures. Container shape, $S$, was not significant for the final quality within the ranges of variable values simulated. Figure 4 shows the predicted response (cupuaçu volume average vitamin $\mathrm{C}$ retention) surface as a function of the main variables (filling temperature and pasteurization value), for water cooling at $20^{\circ} \mathrm{C}$. A total of 27 simulation results were used for the surface prediction. This figure reinforces the conclusions taken from the Pareto chart (Fig. 3). Final quality is greatly improved when using higher filling temperatures. Minimum pasteurizatior values also give better quality, although temperature is the major variable for maximum quality retention. The quadratic effect of temperature $\left(T_{F}\right)^{2}$ within the

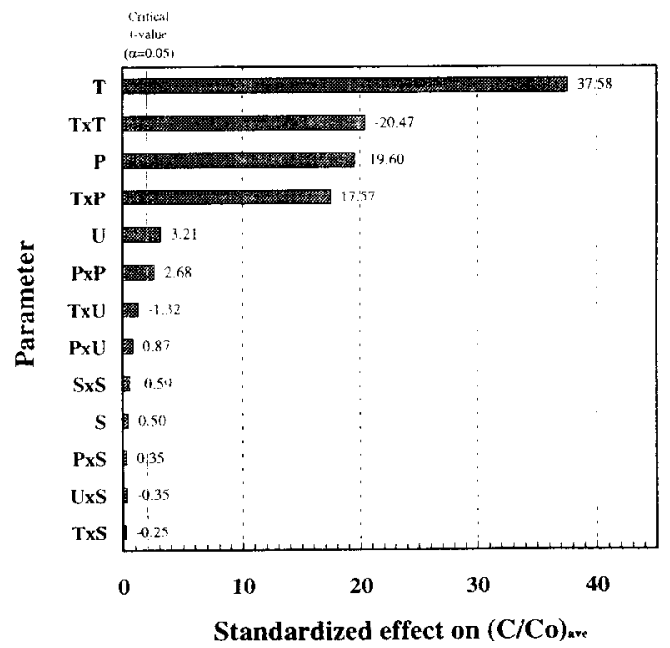

Fig. 3. Pareto chart for the evaluation of several parameter standardized effects on product volume average quality retention $\left(T=T_{\mathrm{F}}, P=P_{\text {ave }}\right)$. 


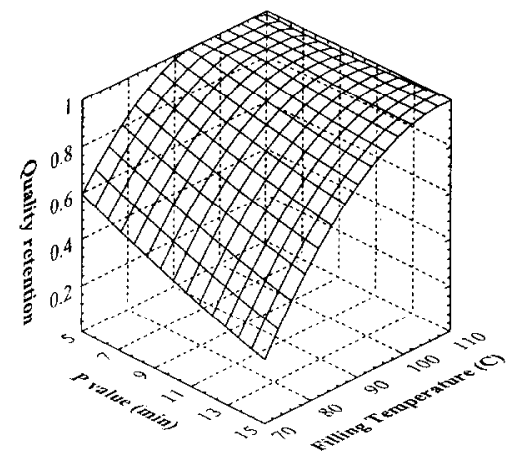

Fig. 4. Effect of filling temperature and pasteurization value on the predicted response surface $\left(C / C_{0}\right)_{\text {ave }}$, for water cooling at $20^{\circ} \mathrm{C}$.

$P_{\text {ave }}$ range is apparent from the surface shape shown in Fig. 4. The interaction effect of temperature and pasteurization value $\left(T_{\mathrm{F}} \times \mathrm{P}_{\text {ave }}\right)$ is also clear because at $70^{\circ} \mathrm{C}$ quality is much more sensitive to $P_{\text {ave }}$ than at $110^{\circ} \mathrm{C}$.

Since no real kinetic data for vitamin $\mathrm{C}$ or $\mathrm{PE}$ inactivation in cupuaçu is available, an experimental validation of the conclusions drawn from this theoretical study would be very important. This subject will be object of further work in this research area.

\section{ACKNOWLEDGEMENTS}

The author Filipa M. Silva acknowledges PRAXIS XXI grant for financial support to Ministério da Ciência e Tecnologia, Portugal. The authors thank Jesus Frias Celayeta and Pedro Manso Pereira for their opportune and important comments during this research study. The authors also acknowledge the research financial support of the European Union, contract STD no. ERB-TS3-CT94-0300, project 'Etude Pluridisciplinaire de Transformations de Fruits Amazoniens en Vue de Leur Valorisation Commerciale par les Organisations Paysannes Existantes'.

\section{REFERENCES}

Alvarado, J. D. \& Viteri, N. P. (1989). Efecto de la temperatura sobre la degradacion aerobica de vitamina $C$ en jugos de frutas citricas. Arch. Latinoam. Nutricion, 39(4), 601-612.

Argáiz, A. (1994). Thermal inactivation kinetics of pectinesterase in acidified papaya nectar and purecs. Rev. Esp. Cienc. Tecnol. Alimentos, 34(3), 301-309.

Aung, T. \& Ross, E. (1965). Heat sensitivity of pectinesterase activity in papaya puree and of catalase-like activity in passion fruit juice. J. Food Sci., 30, 144-147. 
Banga, J. R., Alonso, A. A., Gallardo, J. M. \& Perez-Martin, R. I. (1993). Computer aided design and optimization of sterilization of canned tuna. Presented at ICEF6, 23-27 May, Chiba, Japan.

Barbosa, W. C., Nazaré, R. F. R. \& Nagata, I. (1978). Estudos físicos e químicos dos frutos: bacuri (Platonia insignis), cupuaçu (Theobroma grandiflorum) e murici (Byrosonima crassifolia). An. Congresso Brasil. Fruticult., 5, 797-808.

Box, G. E. P. \& Behnken, D. W. (1960). Some new three level designs for the study of quantitative variables. Technometrics, 2(4), 455-476.

Box, G. E. P., Hunter, W. G. \& Hunter, J. S. (1978). Statistics for Experiments. Wiley, New York.

Chaar, J. M. (1980). Composição do cupuaçu (Theobroma grandiflorum) e conservação do seu néctar por meio físicos e químicos. Tese de Mestrado, Universidade Federal Rural do Rio de Janeiro, Rio de Janeiro.

Chau, K. V. \& Gaffney, J. J. (1990). A finite-difference model for heat and mass transfer in products with internal heat generation and transpiration. J. Food Sci., 55(2), 484-487.

Chau, K. V. \& Snyder, G. V. (1988). Mathematical model for temperature distribution of thermally processed shrimp. Trans. ASAE, 31(2), 608-612.

Dastur, K., Weckel, K. G. \& Elbe, J. (1968). Thermal processes for canned cherries. Food Technol, , 22, 1176-1182.

Dickerson, R. W. Jr. (1965). An apparatus for the measurement of thermal diffusivity of foods. Food Technol., 19, 198-204.

Fellows, P. (1988). Food Processing Technology. Ellis Horwood, Chichester.

Handschuh, B. (1995). Transport of juices, purees and concentrates. Fruit Processing, 7. 215-217.

Holdsworth, S. D. (1985). Optimisation of thermal processing: a review. J. Food Eng., 4. $89-116$.

Holman, J. P. (1990). Heat Transfer, 7th ed. McGraw-Hill, New York.

IBGE (1981). Tabelas de composição de alimentos. Instituto Brasileiro de Geografia e Estatística, Rio de Janeiro.

Lund, D. B. (1977). Design of thermal processes for maximizing nutrient retention. Food Technol, , 2, 71-78.

Miranda, R. M. (1989). Conservação da polpa de cupuaçu (Theobroma grandiflorum Schum.) com uso do frio. Tese de Mestrado. INPA/Fundação Universidade do Amazonas, Manaus.

Nanjundaswamy, A. M., Saroja, S. \& Ranganna, S. (1973). Determination of thermal process for canned mango products. Ind. Food Packer, 27(6), 5-13.

Nath, N. \& Ranganna, S. (1977). Time-temperature relationship for thermal inactivation of pectinesterase in Mandarin orange (Citrus reticulata blanco) juice. J. Food Technol., 12, $411-419$.

Nath, N. \& Ranganna, S. (1980). Determination of thermal schedule for Totapuri mango. J. Food Technol., 15, 251-264.

Nath, N. \& Ranganna, S. (1981). Determination of thermal schedule for acidified papaya. $J$. Food Technol., 46, 201-206, 211.

Nath, N. \& Ranganna, S. (1983a). Heat transfer characteristics and process requirements of hot-filled guava pulp. J. Food Technol., 18, 317-326.

Nath, N. \& Ranganna, S. (1983b). Determination of a thermal process schedule for guava (Psidium guajava Linn.). Food Technol., 18, 301-316.

Oliveira, M. L. S. (1981). Contribuição ao aproveitamento industrial do cupuaçu (Theobroma grandiflorum Schum.). Tese de Mestrado. Universidade Federal Ceará, Fortaleza.

Peralta, E. I., Albastro, E. F., Legaspi, G. R. A. \& Apolinario, K. M. (1973). Growth characteristics and thermal resistance of spoilage organisms isolated from canned peachy papaya given minimal heat treatment. Philippine J. Sci., 102 (1/2).

Saguy, I., Kopelman, I. J. \& Mizrahi, S. (1978). Simulation of ascorbic acid stability during heat processing and concentration of grapefruit juice. J. Food Proc. Eng., 2, 213-225. 
Sandoval, A. J., Barreiro, J. A. \& Mendoza, S. (1994). Prediction of hot-fill-air-cool sterilization processes for tomato paste in glass jars. J. Food Eng., 23, 33-50.

Silva, C. (1993). Optimization of sterilized conduction heating foods: a generalized approach. Ph.D. dissertation, Universidade Católica Portuguesa, Porto, Portugal

Silva, C., Hendrickx, M., Oliveira, F. \& Tobback, P. (1992). Critical evaluation of commonly used objective functions to optimise overall quality and nutrient retention of heat preserved foods. J. Food Eng., 17(4), 241-258.

Silva, C. L. M., Oliveira, F. A. R. \& Hendrickx, M. (1994). Quality optimization of conduction heating foods sterilized in different packages. Int. J. Food Sci. Technol., 29, 515-530.

Sweat, V. E. (1986). Thermal properties of foods. In Engineering properties of foods, eds M. A. Rao \& S. S. H. Rizvi. Marcel Dekker, New York.

Teixeira, A. A., Dixon, J. R., Zahradnik, J. W. \& Zinsmeister, G. E. (1969). Computer optimization of nutrient retention in the thermal processing of conduction-heated foods. Food Technol, 23(6), 137-142.

Van Loey, A., Francis, A., Hendrickx, M., Maesmans, G., Noronha, J. \& Tobback, P. (1993). The optimization of product quality during thermal processing: a case study on white beans in brine. Paper presented at the workshop 'Process optimization and minimal processed foods', 18-24 September 1993, Porto, Portugal. 